\title{
The relationship between soil bacteria substrate utilisation patterns and the vegetation structure in temperate forests
}

\author{
Beata Klimek $^{1} \cdot$ Marcin Chodak $^{2} \cdot$ Małgorzata Jaźwa $^{3} \cdot$ Agata Solak $^{1}$ • \\ Agata Tarasek ${ }^{1} \cdot$ Maria Niklińska ${ }^{1}$
}

Received: 10 June 2015/Revised: 23 November 2015/Accepted: 26 November 2015/Published online: 10 December 2015

(C) The Author(s) 2015. This article is published with open access at Springerlink.com

\begin{abstract}
The aim of the study was to explore the relationship between the functional diversity pattern of soil bacteria and the vegetation diversity and structure in temperate forests (Poland). Pine-dominated forests occur on soils with lower $\mathrm{pH}$, fewer nutrient contents $(\mathrm{P}, \mathrm{Na}, \mathrm{Mg}$, $\mathrm{Mn}$ and $\mathrm{K}$ ) and higher $\mathrm{C} / \mathrm{N}$ and $\mathrm{C} / \mathrm{P}$ ratios than beechdominated forests and mixed broadleaved forest with hornbeam and ash. Both forest type and soil horizon ( $\mathrm{O}$ and A) strongly influenced bacterial catabolic activity and the number of substrates decayed on Biolog ${ }^{\circledR}$ ECO plates. Pine forest soil bacteria were less active and less functionally diverse than those in deciduous forest soils. The community-level physiological profiles (CLPPs) were dissimilar (one-way analysis of similarities) between pine and mixed deciduous forests, but only in the $\mathrm{O}$ soil horizon. Carboxylic acids primarily contributed to the average dissimilarity in CLPP between forests (the similarity percentage procedure); these substrates are preferentially used by pine
\end{abstract}

Handling Editor: Jarmo Holopainen.

Electronic supplementary material The online version of this article (doi:10.1007/s10342-015-0929-4) contains supplementary material, which is available to authorized users.

Beata Klimek

beata.klimek@uj.edu.pl

1 Institute of Environmental Sciences, Faculty of Biology and Earth Sciences, Jagiellonian University, Gronostajowa 7, 30-387 Kraków, Poland

2 Department of Management and Protection of Environment, AGH University of Science and Technology, Mickiewicza 30, 30-059 Kraków, Poland

3 Institute of Botany, Faculty of Biology and Earth Sciences, Jagiellonian University, Kopernika 27, 31-501 Kraków, Poland forest soil bacteria. The canonical correspondence analysis indicated that soil $\mathrm{pH}$, nitrogen and organic matter contents and plant diversity index $H_{\text {plant }}^{\prime}$ were related to bacterial CLPP in the $\mathrm{O}$ soil horizon. Only for the soil $\mathrm{O}$ horizon, the Mantel test showed a clear relationship between vegetation structure and bacterial CLPP.

Keywords Biolog $^{\circledR}$ ECO plates $\cdot$ Biodiversity . Functional diversity · Forest soils · Microbial activity · Microbial community

\section{Introduction}

Soil microorganisms enhance terrestrial ecosystem functioning through the promotion of nutrient cycling, improvements in soil structure formation and fertility and contributions to proper plant nutrition, controlling the energy flow to higher trophic levels in the decomposer food web (de Boer et al. 2005; Schneider et al. 2012). Nevertheless, relationships between plants and soil functions are poorly understood, particularly the complex interactions between plant and soil microorganism diversity (Stephan et al. 2000; Prober et al. 2015). This association has been relatively well recognised for mycorrhizal fungi, as the close relationship between fungi and host plant species is common (Read and Haselwandter 1981). The co-variation of vegetation and soil microorganism diversity can also be expected for free-living soil organisms.

Plants provide litter and root exudates as carbon and nutrients source for the soil decomposer community and regulate the chemistry of the soil solution (Hinsinger et al. 2006; Rodríguez-Loinaz et al. 2008). Both the amount and the chemical composition of litter and root exudates 
depend on the species and growth stage of the plant and on environmental conditions, such as soil moisture and nutrient availability (Grayston et al. 1996; Kuzyakov 2010). It has been hypothesised that plant species-rich communities produce more chemically diverse litters and wider assortments of root exudates, leading to the development of more diverse microbial communities (Kuzyakov 2010; Eisenhauer et al. 2011; Prober et al. 2015).

The vegetation affects a variety of soil microbial characteristics (Tilman et al. 1997; Eisenhauer et al. 2011; Gömöryová et al. 2013) and vice versa, some authors suggest that the soil microbes are the drivers of plant diversity and productivity (van der Heijden et al. 2008). A positive effect of plant diversity on microbial respiration and biomass has also been reported (Eisenhauer et al. 2011). Prober et al. (2015) recently highlighted the relationship between plants and soil microorganisms. In their study, these authors examined the grasslands across four continents, showing that plant diversity predicts the beta, but not alpha, diversity of soil bacteria and fungi. Microbial beta diversity, defined as the variation in community composition (structure), measured as the dissimilarity between plots (Whittaker 1972), is a more relevant measure of plant influence on soil microbes than the alpha diversity, which represents the number and abundance of taxa within communities or habitats.

Most studies concerning relationships between plants and microorganisms have been focused on meadow ecosystems, with modest interest in forest ecosystems. Studies on forests typically only consider dominating tree species, whereas in forests the majority of vegetation biodiversity results from herbaceous plants (Eisenhauer et al. 2011). Only a few studies on forest soil have examined the total effect of all vascular plants on soil microorganisms (Gömöryová et al. 2013; Klimek et al. 2015). For instance, using Biolog ${ }^{\circledR}$ ECO plates, Gömöryová et al. (2013) reported that both plant richness and diversity in an old temperate forest in central Slovakia were positively related to bacterial functional diversity.

Studying soil microorganisms meets many limitations. Next to DNA- and RNA-based methods, the functional diversity approaches remain the most comprehensive strategies. One of the common methods to study soil bacteria functional diversity is community-level physiological profiling (CLPP) using Biolog ${ }^{\circledR}$ plates, based on colorimetric measurements of utilisation of various carbon substrates through microorganisms on microtitre plates (Preston-Mafham et al. 2002; Classen et al. 2003; Rosenvald et al. 2011).

The aim of the present study was to assess the relationship between the diversity and structure of vascular plant assemblages and soil bacteria substrate utilisation patterns on Biolog ${ }^{\circledR}$ ECO plates in three types of temperate forests differing in soil physicochemical characteristics.

\section{Materials and methods}

\section{Study sites and plant diversity determination}

Three types of temperate forests were investigated: a coniferous forest (pine-dominated) and two types of broadleaved forests, beech-dominated and mixed speciesrich forests dominated with hornbeam, alder and ash. The pine-dominated forests stated associations of CladonioPinetum and Vaccinio-Pinetum, Peucedano-Pinetum and Leucobryo-Pinetum with the typical poor forest floor with Cladonia lichens. The beech-dominated forests were associations of Luzulo-Fagenion with Luzulo pilosaeFagetum, Luzulo luzuloides-Fagetum and Dentario glandulosae-Fagetum. The mixed broadleaved forests were associations of Carpinion betuli with Alno-Ulmion, primarily Ficario-Ulmetum minoris and Fraxino-Alnetum. The nomenclature of the plant species was determined according to Mirek et al. (2002), and the plant communities were determined according to Matuszkiewicz (2006).

Stands location was initially picked based on the literature, and final list of stands was chosen after visiting each of them and botanical screening of 1 ha area $\left(10,000 \mathrm{~m}^{2}\right)$. All forest stands were natural as much as it was possible, with exclusion of commercial cultivated forests, but only part of them were protected areas. The age of forest stands was represented by 4 th tree age class that is $60-80$ years.

Each forest type was represented by ten sites distributed throughout Poland. The country mean multiannual temperature ranges from $6{ }^{\circ} \mathrm{C}$ in the northeast to $10{ }^{\circ} \mathrm{C}$ in the southwest, and a mean multiannual precipitation ranges from $550 \mathrm{~mm}$ for the central region of country, increasing gradually to the borders with exception of the west direction, up to $1000 \mathrm{~mm}$ and more on stands located in mountain regions on the south. The sites GPS locations and basic climate characteristics are given in supplementary material (Supl. 1).

The plant species were identified in the field during at least three visits at each site from early spring to summer. The total number of vascular plant species, including trees, shrubs and the forest floor, was counted on representative forest patches (one per stand). The data on the vegetation structure and diversity were obtained from detailed botanical studies in $100-\mathrm{m}^{2}$ area using the Braun-Blanquet method. Vegetation diversity on each site was calculated as $H_{\text {plant }}^{\prime}$ Shannon-Wiener diversity index. The data on plant cover in relevés were transformed from the Braun- 
Blanquet scale into a 0-9 ordinal scale (Piernik 2008), and the $H_{\text {plant }}^{\prime}$ was calculated according to the equation:

$H_{\text {plant }}^{\prime}=-\sum_{i=1}^{s} p_{i} \log _{10} p_{i}$

where $p_{i}$ denotes the frequency for $i$ th species of plant and $s$ is the number of species at a particular site (Piernik 2008).

\section{Soil sampling}

The soil samples were collected in the spring 2013. One sample was collected using a steel core sampler on each site in the centre of a $100-\mathrm{m}^{2}$ plot where plant diversity was determined, and the four samples were collected from four corners around and bulked to obtain one mixed soil sample per plot. The entire $\mathrm{O}$ and $\mathrm{A}$ soil organic horizons were collected to separate bags. The O soil horizon was only collected on the stands, where this horizon was present. Consequently, 30 samples of the A soil horizon and only 22 samples of the $\mathrm{O}$ soil horizon were collected.

The collected soil samples were transported to the laboratory in plastic bags, sieved immediately (O layer through a $1-\mathrm{cm}$ sieve, and A layer through a $0.2-\mathrm{cm}$ sieve) to remove stones, roots and the green parts of the plants to obtain homogenous samples and stored at $4{ }^{\circ} \mathrm{C}$ field-moist until further analyses.

\section{Soil physicochemical analysis}

The soil dry weight (DW) was determined after drying the soil samples at $105{ }^{\circ} \mathrm{C}$ for $24 \mathrm{~h}$, and the organic matter (OM) content was determined as the loss of ignition at $550{ }^{\circ} \mathrm{C}$ for $24 \mathrm{~h}$. Water-holding capacity (WHC) was measured using a gravimetric method (Schlichting and Blume 1966) after soil soaking for $24 \mathrm{~h}$ in net-ended plastic pipes immersed in water. The soil $\mathrm{pH}$ was measured in air-dried subsamples $(1.5 \mathrm{~g})$ shaken in water and in $1 \mathrm{M}$ $\mathrm{KCl}$ solution $(1: 10 \mathrm{w} / \mathrm{v})$ for $1 \mathrm{~h}$ at $200 \mathrm{rpm}$. The total $\mathrm{C}$ and $\mathrm{N}$ contents were analysed in fine-ground soil subsamples using a CHNS analyser (Vario EL III, Elementar Analysensysteme $\mathrm{GmbH}$ ). The total element ( $\mathrm{Ca}, \mathrm{K}, \mathrm{Mg}, \mathrm{Mn}, \mathrm{Na}$ and $\mathrm{P}$ ) concentrations in each soil sample were determined after wet digestion of $0.5 \mathrm{~g}$ of DW in $10 \mathrm{ml}$ of suprapureconcentrated $\mathrm{HNO}_{3}$ and $\mathrm{HClO}_{4}(7: 1 \mathrm{v} / \mathrm{v})$ (Sigma-Aldrich). The concentrations of the elements were measured using atomic absorption spectrometry (AAS) with flame or graphite furnace nebulizer (PerkinElmer). Only the P concentration was measured on the flow-injection analyser (FIA compact, MLE). To assess the accuracy of mineralisation process, four blank samples and three replicates of standard certified material (CRM025-050, Sandy Loam 8,
RT Corp.) were analysed with the soil samples. The $\mathrm{C} / \mathrm{N}$ and $\mathrm{C} / \mathrm{P}$ ratios were calculated for each soil sample. The concentration of dissolved organic carbon (DOC) was measured in water extracts obtained from $3 \mathrm{~g}$ of soil dry mass equivalent shaken for $1 \mathrm{~h}$ at 10:1 water-to-soil ratio at $200 \mathrm{rpm}$ (TOC-V $\mathrm{V}_{\mathrm{CPN}}$, Shimadzu). Each analysis was performed in three subsamples from every soil sample, and the data were averaged and expressed based on the dry weight of the soil.

\section{Biolog $^{\circledR}$ ECO plates analysis}

The catabolic activity and functional diversity of the soil bacteria were analysed using Biolog ${ }^{\circledR}$ ECO plates containing three sets of 31 carbon substrates and tetrazolium dye as the substrate utilisation indicator (http://www.bio log.com). The substrates were classified into six substrate guilds, namely amines, amino acids, carbohydrates, carboxylic acids, polymers and miscellaneous, according to Dobranic and Zak (1999). Prior to the Biolog ${ }^{\circledR}$ analysis, the field-moist soil samples were wetted up to $50 \%$ of their maximal WHC and pre-incubated during 1 week at $22{ }^{\circ} \mathrm{C}$. Subsequently, the equivalent of $2 \mathrm{~g}$ of DW soil was shaken for $1 \mathrm{~h}$ in $20 \mathrm{ml}$ of a $0.9 \% \mathrm{NaCl}$ solution $(\mathrm{pH} \mathrm{7)}$ and settled for approximately $30 \mathrm{~min}$ to decant the soil particles. The suspensions were diluted $\left(10^{-2}\right)$ in $\mathrm{NaCl}$ solution and inoculated onto Biolog ${ }^{\circledR}$ ECO plates (125 $\mu$ l per well) using a multichannel pipette. All plates were incubated in the dark at $22{ }^{\circ} \mathrm{C}$, and substrate utilisation was measured as the light absorbance at $590 \mathrm{~nm}$ ( $\mu$ Quant spectrometer; BIO-TEK Instruments). The first measurement was made immediately after inoculation, and subsequent readings were obtained at 24-h intervals for $168 \mathrm{~h}$. The absorbance measurements for individual wells were corrected against the control well containing only microbial solution. Absorbance values below 0.06 (spectrometer detection limit) were considered as 0 . The number of substrates used by bacteria was counted for each sample.

The general bacterial activity was calculated as the AUC (area under the curve) using the following formula:

$\mathrm{AUC}=\sum_{i=1}^{N} \sum_{t=1}^{n-1} \frac{\left(A_{n}+A_{n+1}\right)}{2} \times\left(t_{n+1}-t_{n}\right)$

where $A_{n}$ and $A_{n+1}$ are the absorbance of each individual well at two consecutive measurements at times $t_{n}$ and $t_{n+1}$, $n$ represents particular measurements (scorings), and $N$ represents the number of substrates on the plate (31 for ECO plates) (Hackett and Griffiths 1997). Because both the density and the activity of microbial cells affect the rate of colour development, the community-level physiological profiles (CLPP) were compared at the same sample average well colour development (AWCD), calculated as on the 
mean well absorbance, to compensate for differences in the initial inoculum density $(\mathrm{AWCD}=0.09$, irrespective of the incubation time) (Garland 1997; Preston-Mafham et al. 2002). The absorbance values for individual wells/substrates were expressed as a proportion of the total sample absorbance on the plate, standardised to 1 for each sample. In addition, the mean absorbance for each site was divided into six substrate guilds: amines, amino acids, carbohydrates, carboxylic acids, polymers and miscellaneous, according to Dobranic and Zak (1999).

\section{Statistical analyses}

One-way ANOVA was performed to examine the differences in the mean plant species number, mean tree species number and plant diversity index $H_{\text {plant }}^{\prime}$ between the studied forest types. The normality criterion for the data distribution within groups was assessed using the Shapiro-Wilk test, and data were transformed if needed. The results were considered significant at $p<0.05$. Pairwise differences of means were tested by Tukey's test.

Differences in soil physicochemical characteristics (OM, WHC, $\mathrm{pH}$ in water and $\mathrm{KCl}$, concentrations of chemical elements, $\mathrm{C} / \mathrm{N}$ and $\mathrm{C} / \mathrm{P}$ ratios, DOC concentrations) between three forest types and two soil organic horizons were compared with two-way ANOVA with Tukey's test $(p<0.05)$. Also differences in means of bacterial activity AUC and number of substrates used on plates between forest types and soil organic layers were compared with two-way ANOVA with Tukey's test $(p<0.05)$.

One-way analysis of similarities (ANOSIM) was used to examine significant differences in the CLPP under the studied forest types. ANOSIM is a nonparametric permutation procedure to compare between-groups and withingroups dissimilarities (Clarke and Green 1988). This procedure calculates $R$ statistic, wherein $R=0$ indicates completely random grouping and $R=1$ only if all replicates within groups are more similar to each other than any replicates across groups. Global $R$ value was used to express overall dissimilarity between the stands. The significant global $R$ values indicated that the $R$ value to differ significantly from 0 suggests that the compared sites were significantly dissimilar. Dissimilarities between the stands based on Bray-Curtis distances were tested in pairwise comparisons, and their significance was assessed according to the sequential Bonferroni procedure.

The similarity percentage (SIMPER) procedure was applied to identify which chemical guilds contributed most to the average dissimilarity between the forest types (Clarke 1993). To identify discriminating features, this procedure calculates the average Bray-Curtis dissimilarity between all pairs of inter-group samples, and the average dissimilarity between main factors (forest types) can be expressed in terms of the average contribution from each variable. The standard deviation provides a measure of how consistently a given variable (substrate chemical guild) contributes to the dissimilarity between forest types.

Both ANOSIM and SIMPER procedures were applied for data on the $\mathrm{O}$ and A soil horizons, separately.

Canonical correspondence analysis (CCA) was used to examine the correlation between the CLPP with the soil properties and vegetation diversity in different forests, with backward factors selection. CCA analysis was performed separately for stands with $\mathrm{O}$ and $\mathrm{A}$ soil horizons. In this analysis, we used the $\mathrm{N}$ content to represent nutrient availability and the MO content to represent the soil wealth, and the soil $\mathrm{pH}$ measure in $1 \mathrm{M} \mathrm{KCl}$ solution represented the potential soil acidity and $H_{\text {plant }}^{\prime}$ represented the influence of vegetation diversity on CLPP.

In order to compare CLPPs of soil bacterial communities and the structure of vegetation in the studied forest types, we calculated similarity matrices based on BrayCurtis distances using either the Biolog ${ }^{\circledR}$ data (separately for the $\mathrm{O}$ and $\mathrm{A}$ horizons) or the botanical data. The matrices were then compared using the Mantel test (5000 permutations).

The $H_{\text {plant }}^{\prime}$ was calculated using MSVP 3.22 software (Kovach Computing Services, Pentraeth, UK). ANOVAs were conducted using Statgraphics Centurion XVI (StatPoint Technologies Inc., Warrenton VA, USA) and multivariate analyses PAST $2.17 \mathrm{c}$ software (Natural History Museum, University of Oslo, Norway).

\section{Results}

\section{Vegetation diversity}

Totally, 147 vascular plant species were identified from the studied sites. The forest types differed in the mean number of vascular plant species $(p<0.0001)$ with the mixed broadleaved forests, characterised as the highest number of plant species (Table 1). These were observed also for mean number of tree species (Table 1). The $H_{\text {plant }}^{\prime}$ index differed only amongst the pine-dominated and mixed broadleaved forests (Table 1).

\section{Soil physicochemical characteristics}

Coniferous forests occurred on soils with lower $\mathrm{pH}$ and containing fewer nutrients ( $\mathrm{P}, \mathrm{Na}, \mathrm{Mg}, \mathrm{Mn}, \mathrm{K}$ ) (Tables 2, 3). This result was confirmed based on higher $\mathrm{C} / \mathrm{N}$ and $\mathrm{C} / \mathrm{P}$ ratios compared with other forests (Table 2). Nevertheless, 
Table 1 Mean values and standard deviations for plant diversity characteristics: total number of vascular plant species, number of tree species and $H_{\text {plant }}^{\prime}$ index

\begin{tabular}{|c|c|c|c|}
\hline & \multicolumn{3}{|c|}{ Vegetation diversity characteristics } \\
\hline & Total number of species & Number of tree species & $H_{\text {plant }}^{\prime}$ \\
\hline \multicolumn{4}{|l|}{ Forest type } \\
\hline Pine & 10.8 a $(8.2)$ & 1.8 a $(0.9)$ & 0.80 a $(0.44)$ \\
\hline Beech & 13.9 a $(6.1)$ & $2.3 \mathrm{a}(1.3)$ & $1.04 \mathrm{ab}(0.19)$ \\
\hline Mixed broadleaved & $28.5 \mathrm{~b}(8.3)$ & $5.5 \mathrm{~b}(1.9)$ & $1.38 \mathrm{~b}(0.16)$ \\
\hline$p$ value & 0.0001 & 0.0000 & 0.0004 \\
\hline
\end{tabular}

One-way ANOVA test results ( $p$ value) were presented; significant differences (if existed) between forests were indicated by small letters $(a, b, c)$
Table 2 Mean values and standard deviations for soil physicochemical properties: organic matter content $(\mathrm{OM} \%)$, maximum waterholding capacity (WHC \%), dissolved organic carbon content $\left(\mathrm{mg} \mathrm{g}^{-1} \mathrm{DW}\right)$, soil $\mathrm{pH}$ measured in water and in $1 \mathrm{M} \mathrm{KCl}$ solution, content of $\mathrm{C}, \mathrm{N}, \mathrm{P}(\% \mathrm{DW})$ and $\mathrm{C} / \mathrm{N}$ and $\mathrm{C} / \mathrm{P}$ ratios

\begin{tabular}{|c|c|c|c|c|c|c|c|c|c|c|c|}
\hline \multirow[t]{2}{*}{ Forest type } & \multirow{2}{*}{$\begin{array}{l}\text { Soil } \\
\text { horizon }\end{array}$} & \multicolumn{10}{|c|}{ Soil physicochemical parameter } \\
\hline & & $\begin{array}{l}\text { OM } \\
\text { (\% DW) }\end{array}$ & WHC & $\begin{array}{l}\text { DOC } \\
\left(\mathrm{mg} \mathrm{g}^{-1}\right. \\
\mathrm{DW})\end{array}$ & $\begin{array}{l}\mathrm{pH} \text { in } \\
\text { water }\end{array}$ & $\begin{array}{l}\mathrm{pH} \text { in } \\
\mathrm{KCl}\end{array}$ & $\begin{array}{l}\mathrm{C} \\
(\% \mathrm{DW})\end{array}$ & $\mathrm{N}$ & $\mathrm{P}$ & $\begin{array}{l}\mathrm{C} / \mathrm{N} \\
(-)\end{array}$ & $\mathrm{C} / \mathrm{P}$ \\
\hline Pine & $\mathrm{O}$ & $\begin{array}{r}64.2 \mathrm{aB} \\
(13.1)\end{array}$ & $\begin{array}{c}408.6 \mathrm{aB} \\
(77.8)\end{array}$ & $\begin{array}{r}0.87 \mathrm{aB} \\
(0.23)\end{array}$ & $\begin{array}{l}3.98 \mathrm{a} \\
(0.52)\end{array}$ & $\begin{array}{l}3.15 \mathrm{a} \\
(0.57)\end{array}$ & $\begin{array}{c}31.22 \mathrm{aB} \\
(5.30)\end{array}$ & $\begin{array}{r}0.94 \mathrm{aB} \\
(0.15)\end{array}$ & $\begin{array}{r}0.051 \mathrm{aB} \\
(0.010)\end{array}$ & $\begin{array}{c}33.5 \mathrm{cB} \\
(4.9)\end{array}$ & $\begin{array}{c}608 \mathrm{cB} \\
(96)\end{array}$ \\
\hline Beech & & $\begin{array}{r}73.2 \mathrm{bB} \\
(16.2)\end{array}$ & $\begin{array}{r}610.4 \mathrm{bB} \\
(129.0)\end{array}$ & $\begin{array}{c}1.71 \mathrm{bB} \\
(0.53)\end{array}$ & $\begin{array}{l}5.25 \mathrm{~b} \\
(0.58)\end{array}$ & $\begin{array}{l}4.62 \mathrm{~b} \\
(0.76)\end{array}$ & $\begin{array}{c}35.24 \mathrm{bB} \\
(7.32)\end{array}$ & $\begin{array}{r}1.37 \mathrm{bB} \\
(0.29)\end{array}$ & $\begin{array}{r}0.072 \mathrm{bB} \\
(0.011)\end{array}$ & $\begin{array}{c}25.8 \mathrm{bB} \\
(2.9)\end{array}$ & $\begin{array}{c}487 \mathrm{bB} \\
(85)\end{array}$ \\
\hline $\begin{array}{l}\text { Mixed } \\
\text { broadleaved }\end{array}$ & & $\begin{array}{c}48.1 \mathrm{aB} \\
(9.9)\end{array}$ & $\begin{array}{r}406.8 \mathrm{aB} \\
(117.7)\end{array}$ & $\begin{array}{r}1.22 \mathrm{aB} \\
(0.66)\end{array}$ & $\begin{array}{l}5.32 \mathrm{~b} \\
(0.72)\end{array}$ & $\begin{array}{l}4.88 \mathrm{~b} \\
(0.83)\end{array}$ & $\begin{array}{c}26.82 \mathrm{aB} \\
(8.90)\end{array}$ & $\begin{array}{c}1.37 \mathrm{bB} \\
(0.38)\end{array}$ & $\begin{array}{r}0.075 \mathrm{bB} \\
(0.013)\end{array}$ & $\begin{array}{c}19.5 \mathrm{aB} \\
(1.9)\end{array}$ & $\begin{array}{r}361 \mathrm{aB} \\
(112)\end{array}$ \\
\hline Pine & A & $\begin{array}{r}5.4 \mathrm{aA} \\
(2.5)\end{array}$ & $\begin{array}{c}53.8 \mathrm{aA} \\
(13.6)\end{array}$ & $\begin{array}{c}0.56 \mathrm{aA} \\
(0.08)\end{array}$ & $\begin{array}{l}4.38 \mathrm{a} \\
(0.57)\end{array}$ & $\begin{array}{l}3.75 \mathrm{a} \\
(0.60)\end{array}$ & $\begin{array}{c}2.77 \mathrm{aA} \\
(1.31)\end{array}$ & $\begin{array}{c}0.13 \mathrm{aA} \\
(0.06)\end{array}$ & $\begin{array}{r}0.009 \mathrm{aA} \\
(0.006)\end{array}$ & $\begin{array}{c}22.2 \mathrm{cA} \\
(2.6)\end{array}$ & $\begin{array}{r}338 \mathrm{cA} \\
(120)\end{array}$ \\
\hline Beech & & $\begin{array}{c}19.7 \mathrm{bA} \\
(2.5)\end{array}$ & $\begin{array}{c}171.8 \mathrm{bA} \\
(49.5)\end{array}$ & $\begin{array}{c}0.73 \mathrm{bA} \\
(0.16)\end{array}$ & $\begin{array}{l}4.82 \mathrm{~b} \\
(0.70)\end{array}$ & $\begin{array}{l}4.10 \mathrm{~b} \\
(0.73)\end{array}$ & $\begin{array}{c}9.72 \mathrm{bA} \\
(4.27)\end{array}$ & $\begin{array}{c}0.60 \mathrm{bA} \\
(0.28)\end{array}$ & $\begin{array}{c}0.039 \mathrm{bA} \\
(0.014)\end{array}$ & $\begin{array}{c}16.2 \mathrm{bA} \\
(3.5)\end{array}$ & $\begin{array}{r}252 \mathrm{bA} \\
(106)\end{array}$ \\
\hline $\begin{array}{l}\text { Mixed } \\
\text { broadleaved }\end{array}$ & & $\begin{array}{c}13.8 \mathrm{aA} \\
(6.8)\end{array}$ & $\begin{array}{c}125.5 \mathrm{aA} \\
(55.8)\end{array}$ & $\begin{array}{c}0.35 \mathrm{aA} \\
(0.22)\end{array}$ & $\begin{array}{l}5.17 \mathrm{~b} \\
(1.01)\end{array}$ & $\begin{array}{l}4.66 \mathrm{~b} \\
(1.20)\end{array}$ & $\begin{array}{c}6.36 \mathrm{aA} \\
(3.30)\end{array}$ & $\begin{array}{c}0.46 \mathrm{bA} \\
(0.21)\end{array}$ & $\begin{array}{c}0.045 \mathrm{bA} \\
(0.012)\end{array}$ & $\begin{array}{c}13.4 \mathrm{aA} \\
(2.1)\end{array}$ & $\begin{array}{c}150 \mathrm{aA} \\
(70)\end{array}$ \\
\hline \multicolumn{12}{|c|}{ ANOVA main effects } \\
\hline Forest type & & 0.0002 & 0.0000 & 0.0000 & 0.0002 & 0.0002 & 0.0000 & 0.0000 & 0.0000 & 0.0000 & 0.0000 \\
\hline Soil layer & & 0.0001 & 0.0000 & 0.0000 & 0.8870 & 0.9823 & 0.0000 & 0.0000 & 0.0000 & 0.0000 & 0.0000 \\
\hline Interaction & & 0.0071 & 0.0278 & 0.0033 & - & - & 0.0001 & 0.0000 & 0.0000 & - & - \\
\hline
\end{tabular}

Two-way ANOVA test results ( $p$ value) were presented at the bottom of the table; significant differences (if existed) between forests were indicated by small letters $(\mathrm{a}, \mathrm{b}, \mathrm{c})$ and between soil layers by large letters $(\mathrm{A}, \mathrm{B})$

highly significant interactions between the forest type and soil horizon were observed for some physicochemical soil characteristics. In each forest type, less decomposed material from the $\mathrm{O}$ horizon showed higher OM, DOC, C, $\mathrm{N}, \mathrm{P}, \mathrm{Ca}$ and $\mathrm{Mn}$ contents and higher $\mathrm{C} / \mathrm{N}$ and $\mathrm{C} / \mathrm{P}$ ratios (Tables 2, 3).

\section{Soil bacteria characteristics}

Pine-dominated forests were characterised by lower mean bacterial activity AUC than deciduous forest $(p<0.0001)$, and the A soil horizon was characterised by a lower AUC than the O horizon $(p<0.0001)$ (Fig. 1). However, a significant interaction between the forest type and soil horizon $(p=0.0384)$ indicated differences in the mean AUC between soil horizons only for both deciduous forest types (Fig. 1).

The mean number of substrates used on Biolog ${ }^{\circledR}$ ECO plates was lowest for bacteria from pine forest soil and highest for bacteria from mixed broadleaved forest soil $(p=0.0265)$; beech forest soil bacteria utilised an intermediate number of substrates (Fig. 2). A lower mean number of substrates were utilised on Biolog ${ }^{\circledR}$ ECO plates by bacteria from the A soil horizon compared with the $\mathrm{O}$ horizon ( $p=0.0029$ ) (Fig. 2). 
Table 3 Mean values and standard deviations for total microelements contents in soil: $\mathrm{Na}, \mathrm{Ca}, \mathrm{Mg}, \mathrm{Mn}, \mathrm{K}\left(\mathrm{mg} \mathrm{kg}^{-1} \mathrm{DW}\right.$ )

\begin{tabular}{|c|c|c|c|c|c|c|}
\hline \multirow[t]{2}{*}{ Forest type } & \multirow[t]{2}{*}{ Soil horizon } & \multicolumn{5}{|l|}{ Elements content } \\
\hline & & $\begin{array}{l}\mathrm{Ca} \\
\left(\mathrm{mg} \mathrm{kg}^{-1} \mathrm{DW}\right)\end{array}$ & $\mathrm{K}$ & $\mathrm{Mg}$ & $\mathrm{Mn}$ & $\mathrm{Na}$ \\
\hline Pine & $\mathrm{O}$ & $1158 \mathrm{aB}(1279)$ & 620 a (118) & 342 a (109) & $136 \mathrm{aB}(93)$ & 50 a (16) \\
\hline Beech & & 10,074 bB (5506) & 1753 b (808) & 984 b (481) & 1074 bB (548) & 79 b (26) \\
\hline Mixed broad & & 12,826 bB (6671) & 2385 b (1702) & 1346 b (1320) & 2996 bB (94) & 62 b (39) \\
\hline Pine & A & 426 aA (649) & 289 a (105) & 136 a (91) & 36 aA (26) & 20 a (5) \\
\hline Beech & & 1648 bA (1841) & 4226 b (3224) & 1450 b (1257) & 564 bA (475) & $171 \mathrm{~b}(91)$ \\
\hline Mixed broad & & 4151 bA (6429) & 2700 b (1738) & 1306 b (864) & 912 bA (959) & 118 b (69) \\
\hline \multicolumn{7}{|c|}{ ANOVA main effects } \\
\hline Forest type & & 0.0000 & 0.0001 & 0.0000 & 0.0000 & 0.0000 \\
\hline Soil layer & & 0.0000 & 0.1096 & 0.2162 & 0.0001 & 0.4049 \\
\hline \multicolumn{2}{|c|}{ Interaction (forest $\times$ horizon) } & - & - & 0.0157 & - & 0.0000 \\
\hline
\end{tabular}

Two-way ANOVA test results ( $p$ value) were presented at the bottom of the table; significant differences (if existed) between forests were indicated by small letters $(\mathrm{a}, \mathrm{b}, \mathrm{c})$ and between soil layers by large letters $(\mathrm{A}, \mathrm{B})$

The ANOSIM showed that significant differences in CLPPs between forest types were observed only in the $\mathrm{O}$ horizon that is between the pine and beech forests and between the pine and mixed broadleaved forests (Table 4). SIMPER analysis indicated that the largest contribution to the average dissimilarity was from the utilisation of carboxylic acids and polymers (Table 5). The bacteria of pine forest soil were characterised by the highest use of carboxylic acids on Biolog ${ }^{\circledR}$ ECO plates. Moreover, a miscellaneous substrate group showed the most decay rate by bacteria from mixed broadleaved forest soils.

\section{Relationship between plants, soil bacteria and soil properties}

The first two CCA axes calculated for the $\mathrm{O}$ horizon explained $59.85 \% \quad(p=0.0099)$ and $26.85 \%$ $(p=0.0198)$ of the variance, respectively (trace $p=0.0099)$. The first CCA axis was strongly negatively related to $\mathrm{pH}(-0.84)$ and a bit slighter to $H_{\text {plant }}^{\prime}(-0.41)$ and $\mathrm{N}(-0.27)$ and positively to the OM content (0.36). The largest loading to the second axis was from $\mathrm{N}(-0.57)$ and $H_{\text {plant }}^{\prime}(0.30)$.

The pine and both deciduous forests were well separated from each other along the first CCA axis (Fig. 3). The most outstanding stand was $\mathrm{B} 4$, a beech stand more similar to pine forests in terms of OM content. Moreover, this stand was observed to be less fertile than the other beech stands; soil properties, such as the $\mathrm{C} / \mathrm{P}$ ratio or $\mathrm{Ca}$ and $\mathrm{Mn}$ contents, were more similar to the mean for the pine forest than for the beech forest. The pine stand described as P7 was located closer to deciduous forest stands because of the much higher soil $\mathrm{pH}$ in this stand than in other pine stands. The M1 stand was characterised by a much lower N content than the other stands in the mixed broadleaved forest group and was positioned closer to beech forest stands.

The CCA revealed a strong negative relationship between the use of glucose-1-phosphate and soil $\mathrm{N}$ content (Fig. 3). The use of itaconic acid, phenylethyl-amine and 4hydroxy benzoic acid was positively related to soil $\mathrm{pH}$ and the $H_{\text {plant }}^{\prime}$. Strong relationships were also evident between the use of L-threonine and pyruvic acid methyl ester and the OM content.

For the A horizon, the calculated CCA axes were not significant, indicating that the considered soil properties ( $\mathrm{OM}, \mathrm{N}$ and $\mathrm{pH}$ in $\mathrm{KCl}$ ) did not affect physiological abilities of soil microbial communities (data not shown). These results are consistent with the ANOSIM results, indicating similarity between the CLPPs under studied forest stands in the A horizon (Table 4).

The Mantel test showed a significant correlation between vegetation and bacterial CLPP, but only for the soil O horizon $(p=0.0206)$. However, this correlation was relatively weak $(R=0.1653)$.

\section{Discussion}

We observed a significant relationship between the vascular plant assemblage composition and functional (catabolic) soil bacteria diversification measured using Biolog ${ }^{\circledR}$ ECO plates. However, this relationship was only observed for the soil $\mathrm{O}$ horizon and was relatively weak, as soil factors, such as $\mathrm{pH}$ or nutrient contents, also influence 

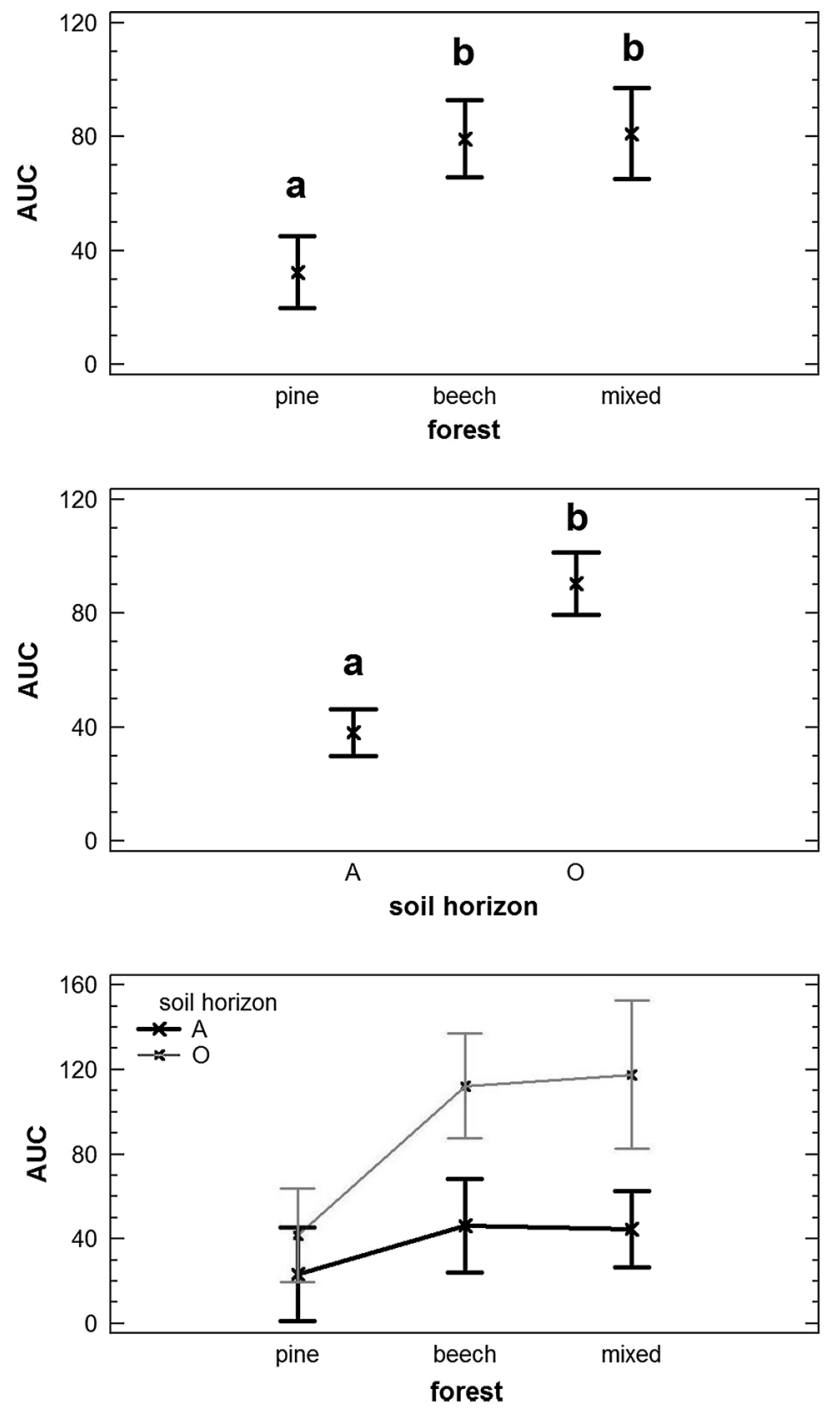

Fig. 1 Bacteria functional activity AUC for forest type, soil horizon and interactive effect between forest type and horizon. Central points indicate the sample means, and error bars indicate $95 \%$ Tukey honestly significant difference intervals. Different letters above bars indicate significant differences in AUC between forests and horizons

bacterial CLPP and overlay plant-mediated effects. These results are consistent with those of previous studies, where relationship between plants and soil microbes communities structure was observed, but soil physicochemical properties were demonstrated as more important drivers of soil microbial properties (Harrison and Bardgett 2010; Thoms et al. 2010).

Soils under different forest types showed diversified soil properties. Pine-dominated forests were observed on poorer stands than both deciduous forest types studied. Dominating tree species affect soil characteristics through the production of litter of different quality (Kiikkilä et al. 2006). Previous studies showed that the share of coniferous versus deciduous trees is the most influencing factor for
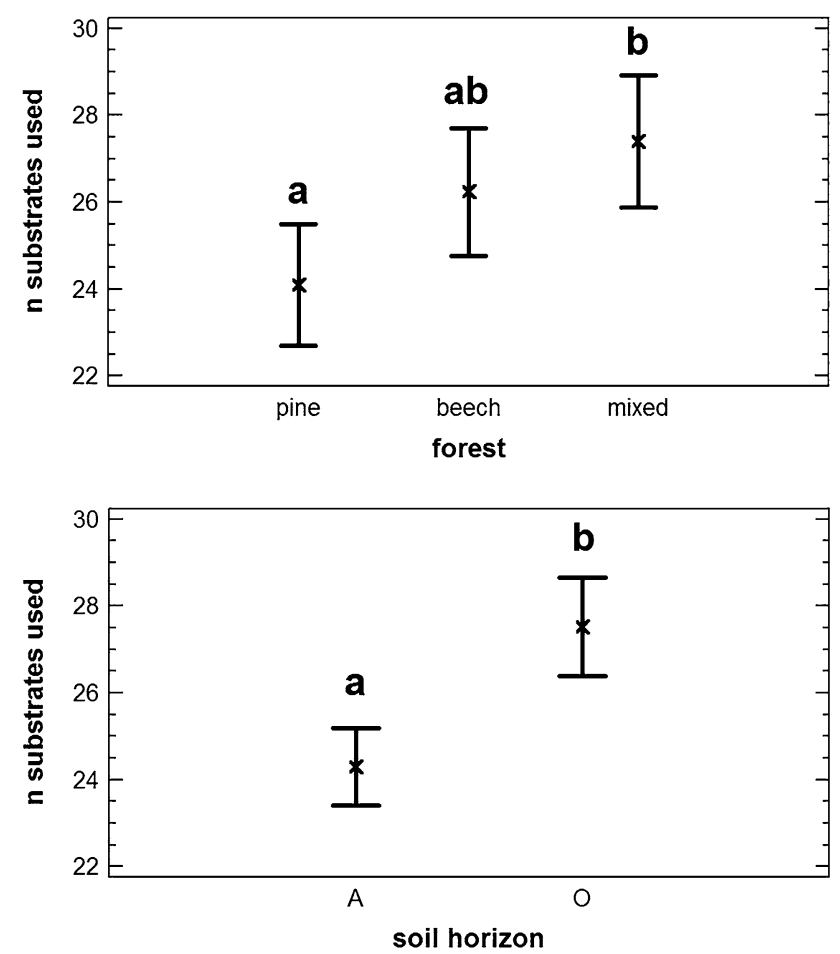

Fig. 2 Bacteria substrates used for forest type and soil horizon. Central points indicate the sample means, and error bars indicate $95 \%$ Tukey honestly significant difference intervals. Different letters above bars indicate significant differences in AUC between forests and horizons

Table 4 ANOSIM on CLPP between the forest types studied

\begin{tabular}{|c|c|c|c|}
\hline Forest type & Pine & Beech & Mixed broadleaved \\
\hline \multicolumn{4}{|l|}{$O$ horizon } \\
\hline \multicolumn{4}{|c|}{ Global values $R=0.262(0.0074)$} \\
\hline Pine & - & $0.998(0.0318)$ & $0.998(0.0267)$ \\
\hline Beech & & - & $0.819(0.8982)$ \\
\hline Mixed broadleaved & & & - \\
\hline \multicolumn{4}{|l|}{ A horizon } \\
\hline \multicolumn{4}{|c|}{ Global values $R=0.052(0.0857)$} \\
\hline Pine & - & $0.066(0.3657)$ & $0.094(0.1395)$ \\
\hline Beech & & - & $-0.004(1.0000)$ \\
\hline Mixed broadleaved & & & - \\
\hline
\end{tabular}

The $R$ values and levels of significance ( $p$ values) according to Bonferroni correction are shown in parentheses. The global $R$ and significance level are also shown. The significantly dissimilar values for pair set are indicated in bold

soil (Chodak and Niklińska 2010; Hansson et al. 2011; Prescott and Grayston 2013). Evergreen coniferous tree species produce litter containing more lignin and leaching more acids, thereby worse decomposing than broadleaved trees litter (Adamczyk et al. 2008). Also tannins, as plant 
Table 5 Results of SIMPER analysis of dissimilarity in CLPP at different forest types for O horizon

\begin{tabular}{|c|c|c|c|c|c|c|}
\hline \multirow[t]{2}{*}{ Substrate chemical guild } & \multicolumn{3}{|l|}{ Dissimilarity measure } & \multicolumn{3}{|l|}{ Mean use } \\
\hline & Average dissimilarity & Contribution $\%$ & Cumulative $\%$ & Pine forest & Beech forest & Mixed broadleaved forest \\
\hline Carboxylic acids & 9.160 & 37.86 & 37.86 & 0.400 & 0.249 & 0.327 \\
\hline Polymers & 5.541 & 22.90 & 60.77 & 0.110 & 0.229 & 0.202 \\
\hline Carbohydrates & 3.141 & 12.98 & 73.75 & 0.153 & 0.197 & 0.141 \\
\hline Miscellaneous & 2.903 & 12.00 & 85.75 & 0.056 & 0.065 & 0.128 \\
\hline Amino acids & 2.609 & 10.79 & 96.54 & 0.172 & 0.213 & 0.208 \\
\hline Amines & 0.838 & 3.463 & 100.00 & 0.038 & 0.038 & 0.026 \\
\hline
\end{tabular}

The term "Contribution" represents the contribution of a substrate group to the average dissimilarity in CLPP between the stands. "Contribution $\%$ " indicates a percentage share of a substrate group to the average dissimilarity. Mean substrate chemical group used by soil bacteria on Biolog ${ }^{\circledR}$ ECO plates is sum of the relative use of substrate groups, scaled from 0 to 1 for particular forest type

secondary metabolites, are more common in coniferous litter and strongly affect soil microorganisms; tannins show stronger negative effects on soil bacteria than on fungi (Ushio et al. 2013).

In the present study, beech and mixed broadleaved forest soils were less acidic and contained more nutrients. The content of elements, such as phosphorus, nitrogen and potassium, are considered limiting for plant productivity (Rousk et al. 2007). Increasing site fertility may cause the floristic change towards more eutrophic assemblages (Rowe et al. 2012). These phenomena were observed in the forest stands along vascular plants diversity gradient. The more fertile the stand, the more diverse plant assemblage was observed. However, as long-lived organisms of much larger size, trees represent greater biomass in temperate forests than herbaceous plant layers and produce a majority of litter and substantial portion of root exudates and dead roots below the ground (Eisenhauer et al. 2010).

In our study, the soil bacteria activity, that is AUC parameter assessed using Biolog ${ }^{\circledR}$ ECO plates, differed between forest types and between soil organic horizons. The significant interaction between these two parameters indicated that the AUC was higher in the O horizon only in beech and mixed broadleaved forests. The upper soil horizon contains more $\mathrm{OM}$ and higher DOC and element concentrations $(\mathrm{Ca}$ and $\mathrm{Mn}$ ), which support high microbial activity. In addition, the mean number of substrates utilised was the lowest for bacteria from pine forest soils. The CLPPs differed between forest types only for soil bacteria from the $\mathrm{O}$ horizon. Namely, the difference in CLPP was observed in the $\mathrm{O}$ soil horizon between pine and beech forests and pine and mixed forests, but not between beech and mixed broadleaved forests.

Priha and Smolander (1999) showed clear separation of CLPP between the rhizosphere bacteria of coniferous and deciduous tree seedlings cultivated in organic soils, but not in mineral soil. However, these authors examined different tree species than those examined in the present study: pine, spruce and birch; the latter tree species have extraordinary high soil biological activity (Rosenvald et al. 2011; Chodak et al. 2015). Fang et al. (2014) observed that pine forest soil bacteria were characterised by a lower functional diversity $H^{\prime}$ Shannon index for Biolog ${ }^{\circledR}$ ECO than mixed and broadleaved forests in the subtropical monsoon climate in South China.

The observation that microbial communities are distinct under coniferous and deciduous forests is also relatively common using other research methods. For example, Ushio et al. (2010) observed distinct microbial communities (PLFA) between two coniferous species compared with three broadleaf species in a mixed forest in Borneo. Moreover, these authors observed an effect in the top $5 \mathrm{~cm}$ of organic soil, confirming that falling litter chemistry has prevailing significance in shaping the soil microbial community. However, studies showing differences in soil microbial communities between different coniferous or deciduous tree species are scarce. For example, Grayston and Prescott (2005) observed a distinct bacteria community (CLPP with Biolog ${ }^{\circledR}$ GN plates) in the upper soil horizon under western red cedar, one of the four coniferous tree species in coastal British Columbia. Recently, Chodak et al. (2015) reported the clear separation of CLPPs measured using the MicroResp ${ }^{\mathrm{TM}}$ method in O horizons under pine-, spruce- and birch-dominated forests in northern Finland. These findings on the functional structure of soil microorganisms in forest stands are associated with dominating tree species.

The differences in soil microorganism metabolic abilities between forest types are commonly attributed to dominating tree species. Still, we observed that the majority of absolute vegetation biodiversity is from the herbaceous layer not the trees species, and there is a statistically significant relationship between bacterial CLPP in the $\mathrm{O}$ soil horizon and total vegetation diversification on 

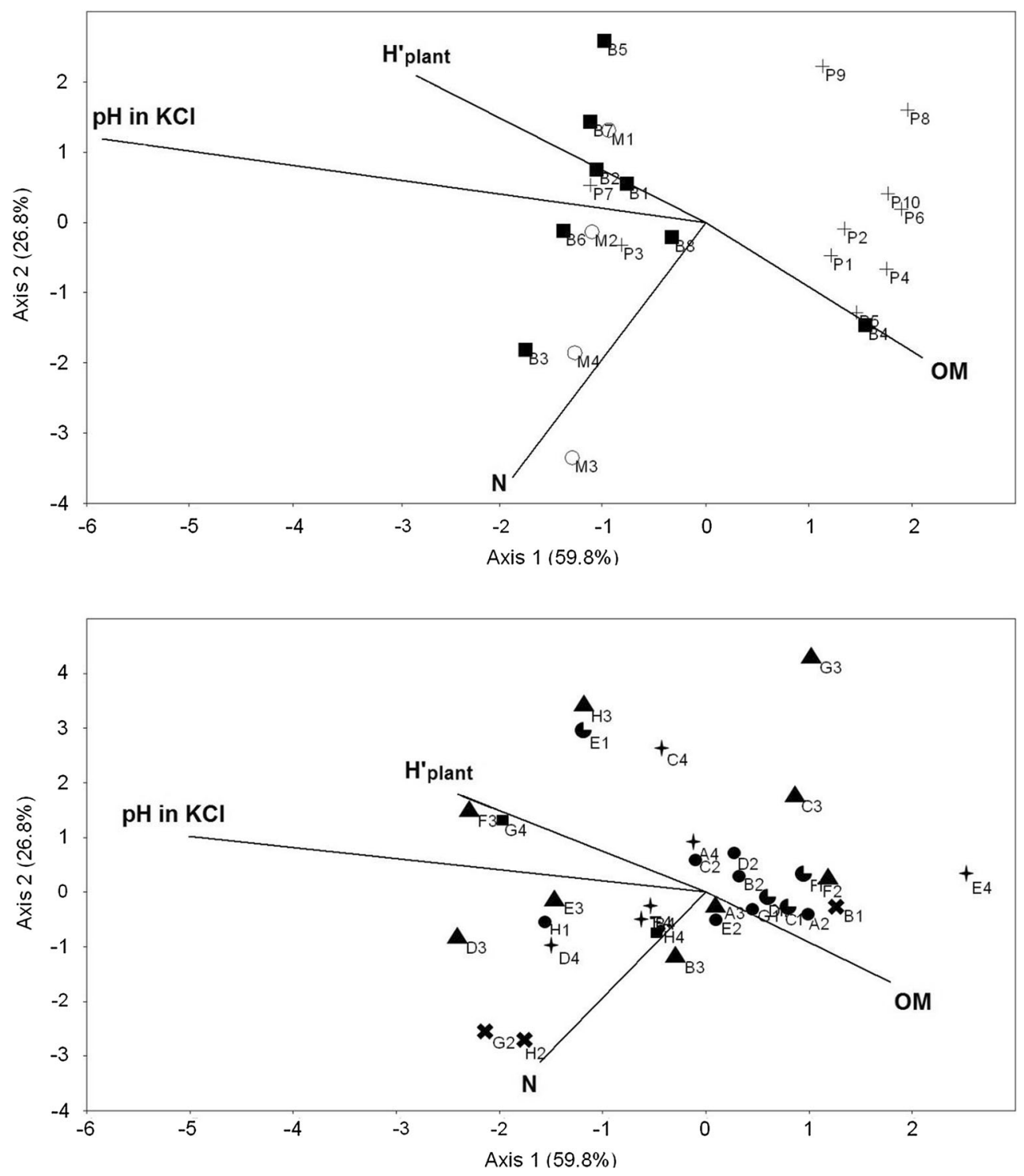

Fig. 3 Canonical correspondence analysis (CCA) ordination plot of the bacteria substrate utilisation pattern (CLPP) according to site properties included soil characteristics: $\mathrm{pH}$ in $\mathrm{KCl}$ and contents of nitrogen $(\mathrm{N})$ and organic matter $(\mathrm{OM})$ and plant diversity index $H_{\text {plant }}^{\prime}$. Analysis results were presented separately for stands distribution (upper figure) and separately for substrates used by soil bacteria (lower figure). Forest stands were denoted with different symbols; hash key symbol denotes pine forest stands, filled quadrate symbols denote beech forest stands, and open round symbols denote mixed broadleaved forest stands; $1,2,3$, etc., are consecutive research stands numeration within group. Chemical substrate guilds were denoted with their position on Biolog ${ }^{\circledR}$ ECO plate (letter and number) and with different symbols; quadrate symbols denote amines (G4phenylethyl-amine, H4-putrescine), narrow hash key symbol

forest stands. These results are consistent with the results of the studies on meadow vegetation diversity gradients (Kowalchuk et al. 2002; Costa et al. 2006). In addition, Zhang and Chu (2011) using Biolog ${ }^{\circledR}$ ECO plates observed that bacterial functional diversity index was positively denotes amino acids (A4-L-arginine, B4-L-asparagine, C4- $\mathrm{L}-$ phenylalanine, D4-L-serine, E4-L-threonine, F4-glycyl-L-glutamic acid), round symbols denote carbohydrates (G1-D-cellobiose, H1- $\alpha$-D-lactose, A2- $\beta$-methyl-D-glucoside, B2-D-xylose, C2-ierythritol, D2-D-mannitol, E2- $N$-acetyl-D-glucosamine), triangle symbols denote carboxylic acids (F2-D-glucosaminic acid, A3-Dgalactonic acid $\gamma$-lactone, B3-D-galacturonic acid, C3-2-hydroxy benzoic acid, D3-4-hydroxy benzoic acid, E3- $\gamma$-hydroxybutyric acid, F3-itaconic acid, G3- $\alpha$-ketobutyric acid, H3-D-malic acid), indent round symbols denote polymers ( $\mathrm{C} 1$ - Tween 40, D1-Tween 80 , E1- $\alpha$-cyclodextrin, F1-glycogen), and $x$-mark denotes miscellaneous (B1-pyruvic acid methyl ester, G2-glucose-1-phosphate, $\mathrm{H} 2$-D,L- $\alpha$-glycerol phosphate)

related to native plant species richness in degraded lands in southern China.

In the present study, the factors shaping CLPP in the O soil horizon were soil $\mathrm{pH}, \mathrm{OM}$ content, nitrogen content and $H_{\text {plant }}^{\prime}$. Soil $\mathrm{pH}$ is one of the most important 
determinants of soil microorganism condition (Dimitriu and Grayston 2010; Chodak et al. 2013). OM and nutrient contents support higher microbial biomass and might indirectly support the increased functional diversity of soil bacteria. We observed that amongst the six chemical substrates used by bacteria on Biolog ${ }^{\circledR}$ ECO plates, carboxylic acids contributed the most to differences in CLPP between forest types in the soil $\mathrm{O}$ horizon, and these substrates were used the most by bacteria from pine forest soils. Using the Biolog ${ }^{\circledR}$ ECO test, Yao et al. (2006) observed the preferential use of carboxylic acids by the microbial community in native pine soil, suggesting that substrate availability supports increased microorganism functional diversification on forest stands. However, carboxylic acids are the biggest contributors amongst the six substrates examined on Biolog ${ }^{\circledR}$ ECO plates (Dobranic and Zak 1999), and carboxylic acid differentiation in the experimental treatments is frequently observed (Chodak and Niklińska 2010; Gu et al. 2014).

\section{Conclusions}

We observed that pine forest created a less active and less diverse bacterial community than deciduous forests. We showed that bacterial CLPP in soil O horizon was associated with vegetation structure. These results are potentially interesting for forestry management in Poland and in Europe to be more ecologically orientated, understanding as protecting biological diversity on all levels of biological organisation.

Acknowledgments This study was financially supported through a grant from the Polish National Science Centre (00421/NZ8/2012/29) and Jagiellonian University (DS 759).

Open Access This article is distributed under the terms of the Creative Commons Attribution 4.0 International License (http://creative commons.org/licenses/by/4.0/), which permits unrestricted use, distribution, and reproduction in any medium, provided you give appropriate credit to the original author(s) and the source, provide a link to the Creative Commons license, and indicate if changes were made.

\section{References}

Adamczyk B, Kitunen V, Smolander A (2008) Protein precipitation by tannins in soil organic horizon and vegetation in relation to tree species. Biol Fertil Soils 45:55-64

Chodak M, Niklińska M (2010) Effect of texture and tree species on microbial properties of mine soils. Appl Soil Ecol 46:268-275

Chodak M, Gołębiewski M, Morawska-Płoskonka J, Kuduk K, Niklińska M (2013) Diversity of microorganisms from forest soils differently polluted with heavy metals. Appl Soil Ecol 64:7-14
Chodak M, Klimek B, Azarbad H, Jaźwa M (2015) Functional diversity of soil microbial communities under Scots pine, Norway spruce, silver birch and mixed boreal forests. Pedobiologia 58:81-88

Clarke KR (1993) Non-parametric multivariate analyses of changes in community structure. Aust J Ecol 18:117-143

Clarke KR, Green RH (1988) Statistical design and analysis for a "biological effects" study. Mar Ecol Prog Ser 46:213-226

Classen AT, Boyle SI, Haskins KE, Overby ST, Hart SC (2003) Community-level physiological profiles of bacteria and fungi: plate type and incubation temperature influences contrasting soils. FEMS Microbiol Ecol 44:319-328

Costa R, Gotz M, Mrotzek N, Lottmann J, Berg G, Smalla K (2006) Effects of site and plant species on rhizosphere community structure as revealed by molecular analysis of microbial guilds. FEMS Microbiol Ecol 56:236-249

de Boer W, Folman LB, Summerbell RC, Boddy L (2005) Living in a fungal world: impact of fungi on soil bacterial niche development. FEMS Microbiol Rev 29:795-811

Dimitriu PA, Grayston SJ (2010) Relationship between soil properties and patterns of bacterial $\beta$-diversity across reclaimed and natural boreal forest soils. Microbiol Ecol 59:563-573

Dobranic JK, Zak JC (1999) A microtiter plate procedure for evaluating fungal functional diversity. Mycologia 91:756-765

Eisenhauer N, Beßler H, Engels C, Gleixner G, Habekost M, Milcu A, Partsch S, Sabais ACW, Scherber C, Steinbeiss S, Weigelt A, Weisser WW, Scheu S (2010) Plant diversity effects on soil microorganisms support the singular hypothesis. Ecology 91:485-496

Eisenhauer N, Yee K, Johnson EA, Maraun M, Parkinson D, Straube D, Scheu S (2011) Positive relationship between herbaceous layer diversity and the performance of soil biota in a temperate forest. Soil Biol Biochem 43:462-465

Fang H, Cheng S, Wang Y, Yu G, Xu M, Dang X, Li L, Wang L (2014) Changes in soil heterotrophic respiration, carbon availability, and microbial function in seven forests along a climate gradient. Ecol Res 29:1077-1086

Garland JL (1997) Analysis and interpretation of community-level physiological profiles in microbial ecology. FEMS Microbiol Ecol 24:289-300

Gömöryová E, Ujházy K, Martinák M, Gömöry D (2013) Soil microbial community response to variation in vegetation and abiotic environment in a temperate old-growth forest. Appl Soil Ecol 68:10-19

Grayston SJ, Vaughan D, Jones D (1996) Rhizosphere carbon flow in trees, in comparison with annual plants: the importance of root exudation and its impact on microbial activity and nutrient availability. Appl Soil Ecol 5:29-56

Grayston S, Prescott C (2005) Microbial communities in forest floors under four tree species in coastal British Columbia. Soil Biol Biochem 37:1157-1167

Gu M, Zhang Z, Wang W, Tang Q, Song S, Zhu J, Xie Y, Zhang L (2014) The effects of radiation pollution on the population diversities and metabolic characteristics of soil microorganisms. Water Air Soil Pollut 225:2133-2141

Hackett CA, Griffiths BS (1997) Statistical analysis of the timecourse of Biolog substrate utilization. J Microbiol Methods 30:67-69

Hansson K, Olsson BA, Olsson M, Johansson U, Kleja DB (2011) Differences in soil properties in adjacent stands of Scots pine, Norway spruce and silver birch in SW Sweden. For Ecol Manag 262:522-530

Harrison KA, Bardgett RD (2010) Influence of plant species and soil conditions on plant-soil feedback in mixed grassland communities. J Ecol 98:348-395 
Hinsinger P, Plassard C, Jaillard B (2006) Rhizosphere: a new frontier for soil biogeochemistry. J Geochem Explor 88:210-213

Kiikkilä O, Kitunen V, Smolander A (2006) Dissolved soil organic matter from surface organic horizons under birch and conifers: degradation in relation to chemical characteristics. Soil Biol Biochem 38:737-746

Klimek B, Niklińska M, Jaźwa M, Tarasek A, Tekielak I, Musielok $Ł$ (2015) Covariation of soil bacteria functional diversity and vegetation diversity along an altitudinal climatic gradient in the Western Carpathians. Pedobiologia 58:105-112

Kowalchuk GA, Buma DS, de Boer W, Klinkhamer PGL, van Veen JA (2002) Effects of above-ground plant species composition and diversity on the diversity of soil-borne microorganisms. Antonie Van Leeuwenhoek 81:509-520

Kuzyakov Y (2010) Priming effects: interactions between living and dead organic matter. Soil Biol Biochem 42:1363-1371

Matuszkiewicz W (2006) Przewodnik do oznaczania zbiorowisk roślinnych Polski [in Polish] (Handbook of forest assemblages identification). Wydawnictwo Naukowe PWN, Warszawa

Mirek Z, Piękoś-Mirkowa H, Zając A, Zając M (2002) Przewodnik do oznaczania zbiorowisk roślinnych Polski [in Polish] (Flowering plants and pteridophytes of Poland. W. Szafer Institute of Botany, Polish Academy of Sciences, Kraków

Piernik A (2008) Metody numeryczne w ekologii-Na przykładzie zastosowań pakietu MVSP do analiz roślinności (Numerical methods in ecology-examples using the vegetation analysis package MVSP). Wydawnictwo Naukowe Nicolaus Copernicus University, Toruń

Priha O, Smolander A (1999) Nitrogen transformations in soil under Pinus sylvestris, Picea abies and Betula pendula at two forest sites. Soil Biol Biochem 31:965-977

Prescott CE, Grayston SJ (2013) Tree species influence on microbial communities in litter and soil: current knowledge and research needs. For Ecol Manag 309:19-27

Preston-Mafham J, Boddy L, Randerson PF (2002) Analysis of microbial community functional diversity using sole-carbonsource utilisation profiles-a critique. FEMS Microbiol Ecol 42:1-14

Prober SM, Leff JW, Bates ST, Borer ET, Firn J, Harpole WS, Lind EM, Seabloom EW, Adler PB, Bakker J, Cleland EE, DeCrappeo NM, DeLorenze E, Hagenah N, Hautier Y, Hofmockel KS, Kirkman KP, Knops JMH, La Pierre KJ, MacDougall AS, McCulley RL, Mitchell CE, Risch AC, Schuetz M, Stevens CJ, Williams RJ, Fierer N (2015) Plant diversity predicts beta but not alpha diversity of soil microbes across grasslands worldwide. Ecol Lett 18:85-95

Read DJ, Haselwandter K (1981) Observations on the mycorrhizal status of some alpine plant communities. New Phytol $88: 341-352$

Rodríguez-Loinaz G, Onaindia M, Amezaga I, Mijangos I, Garbisu C (2008) Relationship between vegetation diversity and soil functional diversity in native mixed-oak forests. Soil Biol Biochem 40:49-60

Rosenvald K, Ostonen I, Truu M, Truu J, Uri V, Vares A, Lõhmus K (2011) Fine-root rhizosphere and morphological adaptations to site conditions in interaction with tree mineral nutrition in young silver birch (Betula pendula Roth.) stands. Eur J For Res 130:1055-1066

Rousk J, Bääth E, Göransson H, Fransson A-M (2007) Assessing plant-microbial competition for ${ }^{33} \mathrm{P}$ using uptake into phospholipids. Appl Soil Ecol 36:233-237

Rowe EC, Emmett BA, Frogbrook ZL, Robinson DA, Hughes S (2012) Nitrogen deposition and climate effects on soil nitrogen availability: influences of habitat type and soil characteristics. Sci Tot Environ 434:62-70

Schlichting E, Blume HO (1966) Bodenkundliches Praktikum. Paul Parey, Hamburg

Schneider T, Keiblinger KM, Schmid E, Sterflinger-Gleixner K, Ellersdorfer G, Roschitzki B, Richter A, Eberl L, ZechmeisterBoltenstern S, Riedel K (2012) Who is who in litter decomposition? Metaproteomics reveals major microbial players and their biogeochemical functions. ISME J 1:1-14

Stephan A, Meyer AH, Schmid B (2000) Plant diversity affects culturable soil bacteria in experimental grassland communities. J Ecol 88:988-998

Thoms C, Gattinger A, Jacob M, Thomas FM, Gleixner G (2010) Direct and indirect effects of tree diversity drive soil microbial diversity in temperate deciduous forests. Soil Biol Biochem 42:1558-1565

Tilman D, Knops J, Wedin D, Reich P, Ritchie M, Siemann E (1997) The influence of functional diversity and composition on ecosystem processes. Science 277:1300-1302

Ushio M, Kitayamaa K, Balser TC (2010) Tree species-mediated spatial patchiness of the composition of microbial community and physicochemical properties in the topsoils of a tropical montane forest. Soil Biol Biochem 42:1588-1595

Ushio M, Balser TC, Kitayama K (2013) Effects of condensed tannins in conifer leaves on the composition and activity of the soil microbial community in a tropical montane forest. Plant Soil 365:157-170

van der Heijden MG, Bardgett RD, van Straalen NM (2008) The unseen majority: soil microbes as drivers of plant diversity and productivity in terrestrial ecosystems. Ecol Lett 11:296-310

Whittaker RH (1972) Evolution and measumerent of species diversity. Taxon 21:213-251

Yao H, Bowman D, Shi W (2006) Soil microbial community structure and diversity in a turfgrass chronosequence: land-use change versus turfgrass management. Appl Soil Ecol 34:209-218

Zhang H, Chu LM (2011) Plant community structure, soil properties and microbial characteristics in revegetated quarries. Ecol Eng $37: 1104-1111$ 